\title{
Homogenization of Maritime Pine Wood Color by Alkaline Hydrogen Peroxide Treatment
}

\author{
Jérémy Mehats ${ }^{1}$, Laurent Castets ${ }^{2}$, Etienne Grau ${ }^{1}$ and Stéphane Grelier ${ }^{1, *(D)}$ \\ 1 CNRS, University of Bordeaux, Bordeaux INP, LCPO, UMR 5629, 33600 Pessac, France; \\ jeremy.mehats.pro@gmail.com (J.M.); etienne.grau@enscbp.fr (E.G.) \\ 2 Gascogne Bois Escource, Route de Cap de Pin, 40210 Escource, France; lcastets@gascognebois.com \\ * Correspondence: sgrelier@enscbp.fr
}

Citation: Mehats, J.; Castets, L.; Grau, E.; Grelier, S. Homogenization of Maritime Pine Wood Color by Alkaline Hydrogen Peroxide Treatment. Coatings 2021, 11, 839. https://doi.org/10.3390/ coatings11070839

Academic Editor: Benedetto Pizzo

Received: 10 June 2021

Accepted: 6 July 2021

Published: 12 July 2021

Publisher's Note: MDPI stays neutral with regard to jurisdictional claims in published maps and institutional affiliations.

Copyright: (C) 2021 by the authors. Licensee MDPI, Basel, Switzerland. This article is an open access article distributed under the terms and conditions of the Creative Commons Attribution (CC BY) license (https:// creativecommons.org/licenses/by/ $4.0 /)$.

\begin{abstract}
The color of maritime pine wood is a critical parameter for manufacturing high added value materials (wood flooring or wood paneling for indoor applications). Actually, the color inhomogeneity between heartwood ( $\mathrm{Hw}$ ) and sapwood (Sw) can lead to a depreciation of the wood value and, therefore, to financial losses for wood products companies. In this article, the development of a color homogenization process based on alkaline hydrogen peroxide chemistry was studied. Maritime pine heartwood and sapwood powders were used to facilitate the chemical characterizations and colorimetric analyses by the CIEL*a* $\mathrm{b}^{*}$ system. Brighter materials were obtained after the treatment by reducing significantly the color difference. The chemical modifications of wood surface were characterized by infrared spectroscopy analyses. The color evolution of the material overtime was also studied thanks to an accelerated ageing under UV irradiation. It was demonstrated that even if a color reversion occurred by oxidation, the color remained homogeneous between heartwood and sapwood.
\end{abstract}

Keywords: heartwood; sapwood; color homogenization; hydrogen peroxide

\section{Introduction}

Maritime pine is one of the most common softwood found in South West of France, covering one million hectares of the country forestry area [1]. It is mainly used for its wood, which possesses good mechanical properties; high elastic modulus (8800 MPa), low density (550 to $750 \mathrm{~kg} \cdot \mathrm{m}^{-3}$ ), and long fibers ( 2.5 to $5 \mathrm{~mm}$ versus 0.8 to $2.5 \mathrm{~mm}$ for hardwood) [2]. These characteristics make maritime pine suitable for packaging purposes (ex: wood pallets) or engineered wood products for indoor and decorative applications (wood flooring, wood paneling). Nevertheless, due to the consumers' feedbacks and specifications, industries identified a major issue: the color difference between heartwood and sapwood. This issue is particularly present in the case of decorative wood where the visual aspect is an important parameter to control.

Wood color is mainly attributed to lignin $[3,4]$ and extractives. Lignin is a polyphenolic macromolecule biosynthesized from coumaryl alcohol, coniferyl alcohol, and synapyl alcohol. Quinone and coniferaldehyde units are known to have the greatest impact on color [5-7]. The latter, which are present only in a low amount in lignin (less than 4\%), [6] absorb light radiations between 300 and $450 \mathrm{~nm}$ (with a maximal absorption at $350 \mathrm{~nm}$ ) [8,9]. Quinones are produced either during the biosynthesis of lignin or by oxidation of phenolic structures. The well-known structures are ortho-quinone $\left(\lambda_{\max }=420 \mathrm{~nm}\right)$ and para-quinone $\left(\lambda_{\max }=373 \mathrm{~nm}\right)$.

Extractives are secondary metabolites. They confer different properties to the wood such as protective effects against insects, mold, and also wood destructive fungi, wood fragrance (terpenes), and color. Phenolic extractives, which have several chromophoric moieties, play a major role on this parameter. According to heartwood type, the synthesis and evolution of those extractives might be different [10]: for Pinus-type heartwood, phenolic precursors are synthetized in sapwood and then modified in the transition zone. 
It was suggested in several studies that those low molecular weight phenolic molecules present in the transition zone evolved into more complex structures within heartwood. This was observed for hardwood [11-14] as well as softwood [15-20]. Even if those complex materials are present in low amount, they can highly influence wood color as shown in the study of Johansson et al. on red cedar wood extractives. An insoluble fraction, with a molar mass between 1000 and $10,000 \mathrm{~g} \cdot \mathrm{mol}^{-1}$, was recovered after extraction and fractionation in methyl t-butyl ether (MTBE), corresponding to only one third of dry matter but being responsible for $70 \%$ of the color of the sample.

Because of these chemical composition differences, maritime pine heartwood has a brown-reddish color while sapwood is yellow.

In addition to homogenization, lighter shades are now more and more appreciated by customers. Treatments based on paper processes chemistry make then suitable candidates for the modification of wood color. Oxidative compounds like oxygen, ozone, or hydrogen peroxide are preferred and commonly employed in Totally Chlorine Free (TCF) bleaching sequences [21-25].

Hydrogen peroxide $\left(\mathrm{H}_{2} \mathrm{O}_{2}\right)$ is usually found in aqueous solutions and, therefore, is more easily handled than the two other oxidants. Quite ineffective when used alone, an alkali as sodium hydroxide $(\mathrm{NaOH})$ is added to produce perhydroxyl anions $\left(\mathrm{HOO}^{-}\right)$, which are better oxidizing agents than the native peroxide [26,27]. $\mathrm{H}_{2} \mathrm{O}_{2}$ stability in solution can be improved by adding metal chelatants or stabilizers like magnesium salts (magnesium sulfate, $\mathrm{MgSO}_{4}$ ) or silicates (sodium metasilicate, $\mathrm{Na}_{2} \mathrm{SiO}_{3}$ ) [28,29]. The reaction between alkaline hydrogen peroxide and wood can be influenced by several parameters: $\mathrm{H}_{2} \mathrm{O}_{2}$ and alkali concentrations, $\mathrm{pH}$, temperature, and treatment duration. Hydrogen peroxide treatment has been used since the 1930s to successfully modify wood color but very few studies $[30,31]$ were made on the influence of the process on the color homogenization between heartwood and sapwood.

Herein, we report in the present study the results of wood color homogenization by alkaline hydrogen peroxide treatments. The experiments were done on wood powders to facilitate the chemical characterizations before and after the treatment. Soxhlet extractions were carried out to observe the effect of the bleaching on the wood extractives' structure. Heartwood ( $\mathrm{Hw}$ ) and sapwood $(\mathrm{Sw})$ were treated separately with a solution composed of hydrogen peroxide, sodium hydroxide, and sodium metasilicate. Color changes were studied with colorimetric analyses and chemical evolutions were observed with infrared analyses. The impacts on wood color of the variation of $\mathrm{NaOH}$ concentration or the substitution of $\mathrm{NaOH}$ by another alkali source were also studied. Finally, ageing experiments under UV irradiation were carried out to examine the behavior of the treated powders overtime.

\section{Materials and Methods}

2.1. Materials and Reagents

2.1.1. Wood Samples

A 60-70 years old maritime pine log with a high red heartwood content was selected in a local sawmill (Gascogne Bois sawmill).

After sawing, wooden boards $\left(200 \times 5 \times 2 \mathrm{~cm}^{3}\right)$ were collected, cut into small pieces $\left(10 \times 5 \times 2 \mathrm{~cm}^{3}\right)$, heartwood and sapwood part were visually determined, cut apart and then milled to reach a 40 -mesh screen [32]. Finally, wood powders were stored at $-20^{\circ} \mathrm{C}$ before further uses. Moisture contents for heartwood and sapwood were, respectively, $20 \pm 2 \%$ and $42 \pm 2 \%$.

\subsubsection{Chemicals}

Hydrogen peroxide $\left(\mathrm{H}_{2} \mathrm{O}_{2}, 35 \%\right.$ in aqueous solution, ACROS Organics), sodium hydroxide $\left(\mathrm{NaOH}, 98 \%\right.$ pellets, Alfa Aesar), sodium metasilicate $\left(\mathrm{Na}_{2} \mathrm{SiO}_{3}\right.$, Sigma Aldrich), and magnesium hydroxide $\left(\mathrm{Mg}(\mathrm{OH})_{2}\right.$, Honeywell Fluka) were used for powder color modification. 
2, 10-dimethylphenanthroline (DMP, 98+\%, Alfa Aesar) and pentahydrate copper(II) sulfate $\left(\mathrm{CuSO}_{4} \cdot 5 \mathrm{H}_{2} \mathrm{O}, \geq 98 \%\right.$ ) were used for spectroscopic monitoring of hydrogen peroxide concentration.

Acetone (99.5+\%, ACROS Organics) was used as a solvent for Soxhlet extraction.

\subsection{Hydrogen Peroxyde Treatment}

For all the experiments, the wood/solvent mass ratio was $1 / 20$. The bleaching solution was composed of $\mathrm{H}_{2} \mathrm{O}_{2}\left(4 \%_{\mathrm{v}}\right)$, alkali $\left(\mathrm{NaOH}\right.$ or $\left.\mathrm{Mg}(\mathrm{OH})_{2} ; 1 \%{ }_{\mathrm{W}}\right)$, and $\mathrm{Na}_{2} \mathrm{SiO}_{3}\left(0.4 \%_{\mathrm{W}}\right)$. Alkali and $\mathrm{Na}_{2} \mathrm{SiO}_{3}$ were first solubilized in water in a round bottom flask. The latter was put in an oil bath and the temperature was set at $60 \pm 1{ }^{\circ} \mathrm{C}$. Then hydrogen peroxyde was added and finally heartwood or sapwood powders were put into the solution under vigorous stirring. After $1 \mathrm{~h}$, the powder was collected, washed with distilled water, filtered, and finally dried in an oven at $50{ }^{\circ} \mathrm{C}$ under vacuum for $12 \mathrm{~h}$. The powder was then stored at room temperature and relative air humidity and kept away from light to prevent any color change.

\subsection{Hydrogen Peroxide Concentration Monitoring}

A spectroscopic method based on Baga et al.'s work was developed [33]. A calibration curve was established first to determine the concentration range for which Beer-Lambert's law was respected (absorbance below 1). During the reaction, a $2.5 \mu \mathrm{L}$ aliquot was collected from the batch and put into a $25 \mathrm{~mL}$-volumetric flask and then filled up with water. Then, $10 \mu \mathrm{L}$ of this solution were taken out, added to a $10 \mathrm{~mL}$-volumetric flask as $1 \mathrm{~mL}$ of a copper (II) sulfate aqueous solution at $0.01 \mathrm{~mol} . \mathrm{L}^{-1}$ and $1 \mathrm{~mL}$ DMP alcoholic solution. A $\left[2 \mathrm{Cu}(\mathrm{DMP})^{2+}\right]$ complex was formed with a maximal absorbance at $454 \mathrm{~nm}$. The Equation (1), following, gives the correlation between hydrogen peroxide concentration and the absorbance:

$$
\left[\mathrm{H}_{2} \mathrm{O}_{2}\right]=\frac{\Delta A_{454 \mathrm{~nm}}}{1500 * \mathrm{~V}_{\mathrm{H}_{2} \mathrm{O}_{2}}}
$$

\subsection{Attenuated Total Reflectance Spectroscopy (ATR)}

ATR analyses were carried out on Bruker Vertex 70 device fitted with a Pike GladiATR plate. Resolution was set at $4 \mathrm{~cm}^{-1}$ and 64 scans were accumulated between 400 and $4000 \mathrm{~cm}^{-1}$ for each experiment.

\subsection{Soxhlet Extraction}

Powders were extracted using a Soxhlet device and acetone as a solvent. Oil bath temperature was set at $75 \pm 1{ }^{\circ} \mathrm{C}$ and the extraction was carried out for $8 \mathrm{~h}$ with a rate of 3-6 siphoning per hour. Extracts were then concentrated and let under dynamic vacuum during a night to remove the last solvent traces. Untreated and peroxide treated powders were extracted to compare the evolution of extractive composition.

\subsection{Colorimetric Analyses}

Wood powders color evolution was monitored by a Nix Pro Color 2 colorimeter. The device source was composed of three High-CRI LEDs and the illuminant D50 was chosen. Observation angle was set at $2^{\circ}$ and optical aperture was fixed at $15 \mathrm{~mm}$. Wood powders were pressed with a laboratory pellet press (Specac, $12.5 \mathrm{MPa}$ applied for $5 \mathrm{~min}$ ) to form $50 \mathrm{~mm}$ diameter discs. Five measurements were performed on the smoothest surface. CIEL ${ }^{*}{ }^{*} b^{*} 1976$ system was used for the study and the value of the three colorimetric parameters L* (lightness), a* (green-red coordinate) and b* (blue-yellow coordinate) could be determined for each sample.

The color difference between heartwood $(\mathrm{Hw})$ and sapwood $(\mathrm{Sw})$ is given by Equation (2):

$$
\Delta \mathrm{E}_{\mathrm{Sw} / \mathrm{Hw}}=\sqrt{\left(\mathrm{L}_{\mathrm{Sw}}^{*}-\mathrm{L}_{\mathrm{Hw}}^{*}\right)^{2}+\left(\mathrm{a}_{\mathrm{Sw}}^{*}-\mathrm{a}_{\mathrm{Hw}}^{*}\right)^{2}+\left(\mathrm{b}_{\mathrm{Sw}}^{*}-\mathrm{b}_{\mathrm{Hw}}^{*}\right)^{2}}
$$


It was aimed in this study to get $\Delta \mathrm{E}_{\mathrm{Sw} / \mathrm{Hw}}$ values as low as possible, so that the color differences are no longer discernible (ideally $\Delta \mathrm{E}_{\mathrm{Sw} / \mathrm{Hw}} \leq 1$ with the colorimetric system used).

\subsection{UV Irradiation Ageing}

Wood discs were irradiated with UV light produced by four black light tubes (TFWN18Mazdafluor). Irradiance was determined with a CCD Thorlab spectrometer $\mathrm{I}_{365 \mathrm{~nm}}=0.45 \mathrm{~mW} . \mathrm{cm}^{-1}$. The temperature was kept under $40{ }^{\circ} \mathrm{C}$ by an air flux. Treated and untreated wood were irradiated for 69 days, and the color was monitored (colorimetric analyses as described in Section 2.6) at regular intervals (measurements every seven days from day 0 to day 49 , last measurement was done on day 69).

\section{Results and Discussion}

\subsection{Modification of Wood Color by Hydrogen Peroxide Treatment}

\subsubsection{Effect on Wood Extractives}

The modifications were observed briefly after the beginning of the peroxide treatment: the color of wood fades and become brighter and the solution becomes yellowish due to the solubilization of extractives. Soxhlet extractions were carried out to observe the influence of the treatment on extractive content. For untreated wood, the yields recovered after extraction were $15.5 \%$ and $7.8 \%$ for heartwood and sapwood, respectively. Those values decrease drastically for the treated samples ( $1 \%$ for $\mathrm{Hw}$ and $0.5 \%$ for $\mathrm{Sw}$ ) supporting the behavior of extractives and showing that their solubilization could have an impact on the coloration of the solution. The only compounds that remain on wood after bleaching are supposed to be fatty acids or sterols derivatives due to their hydrophobicity and low reactivity towards peroxide treatment [34,35].

Chemicals changes were assessed by ATR analyses, Figure 1 shows the differences between untreated and modified heartwood: bands disappearance between $1720-1740 \mathrm{~cm}^{-1}$ (Figure 1a) and between 1690-1700 $\mathrm{cm}^{-1}$ (Figure 1b) corresponding to carbonyl groups that could be associated to various substances, including fatty acids and resins. The same behavior was observed for sapwood powders.

\subsubsection{Color Changes}

Color changes were characterized by colorimetric measurements (Figure 2). For both heartwood and sapwood, a decrease of $a^{*}$ and $b^{*}$ values as well as an increase of $L^{*}$ value have been observed after the treatment. The success of the treatment was highlighted by the determination of $\Delta \mathrm{E}_{\mathrm{Sw} / \mathrm{Hw}}$ values: 6.2 before bleaching versus 1.7 after bleaching.

Heartwood and sapwood discs before and after hydrogen peroxide treatment are observed in Figure 3. 


\section{Heartwood}

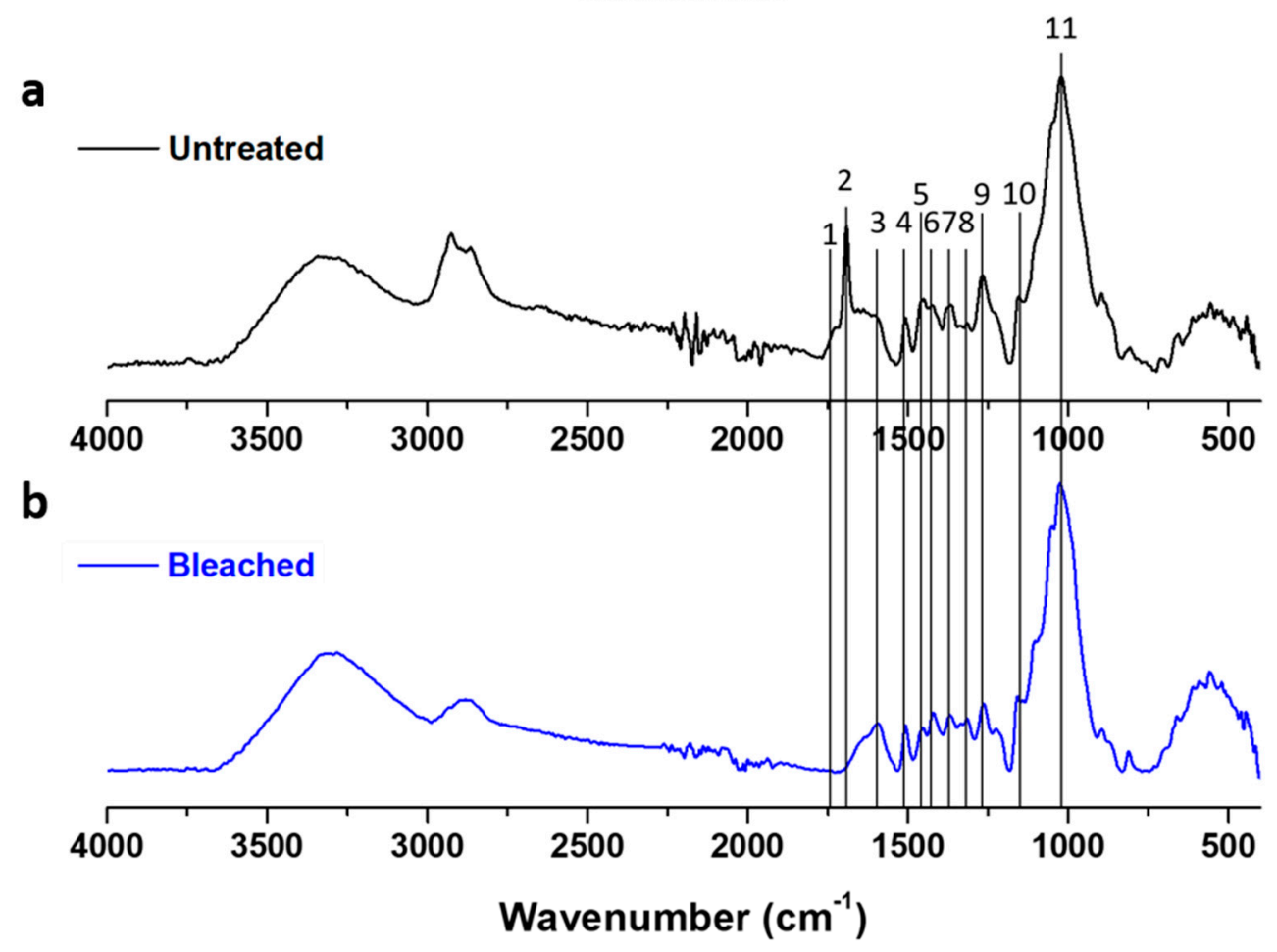

\begin{tabular}{|c|c|c|}
\hline $\mathbf{n}^{\circ}$ & Wavenumber $\left(\mathrm{cm}^{-1}\right)$ & Bonds \\
\hline 1 & $1730-1750$ & $\begin{array}{c}\text { n C }=\mathrm{O} \text { (fatty acids, hemicellulose, } \\
\text { lignin) }\end{array}$ \\
\hline 2 & $1690-1700$ & n C $=\mathrm{O}$ (resin acids) \\
\hline 3 & $1600-1590$ & $\mathrm{n} \mathrm{C}=\mathrm{C}$ (lignin) \\
\hline 4 & $1510-1490$ & $\mathrm{n} \mathrm{C}=\mathrm{C}$ (lignin) \\
\hline 5 & $1440-1460$ & $\mathrm{n} \mathrm{C}=\mathrm{C}$ (lignin) ; $\mathrm{d} \mathrm{CH}, \mathrm{CH}_{2}, \mathrm{CH}_{3}$ (lignin) \\
\hline 6 & $1420-1430$ & $\begin{array}{c}\mathrm{d} \mathrm{CH}_{2} \text { (cellulose), } \mathrm{d} \mathrm{CH} \text { aromatics } \\
\text { (lignin) }\end{array}$ \\
\hline 7 & $1360-1370$ & $\begin{array}{c}\delta \mathrm{CH} \text { (cellulose), } \mathrm{n} \mathrm{CH} \text { aliphatic, } \mathrm{n} \mathrm{OH} \\
\text { phenols }\end{array}$ \\
\hline 8 & $1310-1330$ & n OH (cellulose)/ d CH $(\mathrm{C} 6$, cellulose $)$ \\
\hline 9 & $1260-1270$ & n C-O guaiacyl unit (lignin) \\
\hline 10 & $1150-1160$ & n C-O-C (cellulose) \\
\hline 11 & $1020-1030$ & n C-O (cellulose) \\
\hline
\end{tabular}

Figure 1. ATR spectra of untreated (a) and $\mathrm{H}_{2} \mathrm{O}_{2}$ treated heartwood (b) powders and wavenumbers attribution. 


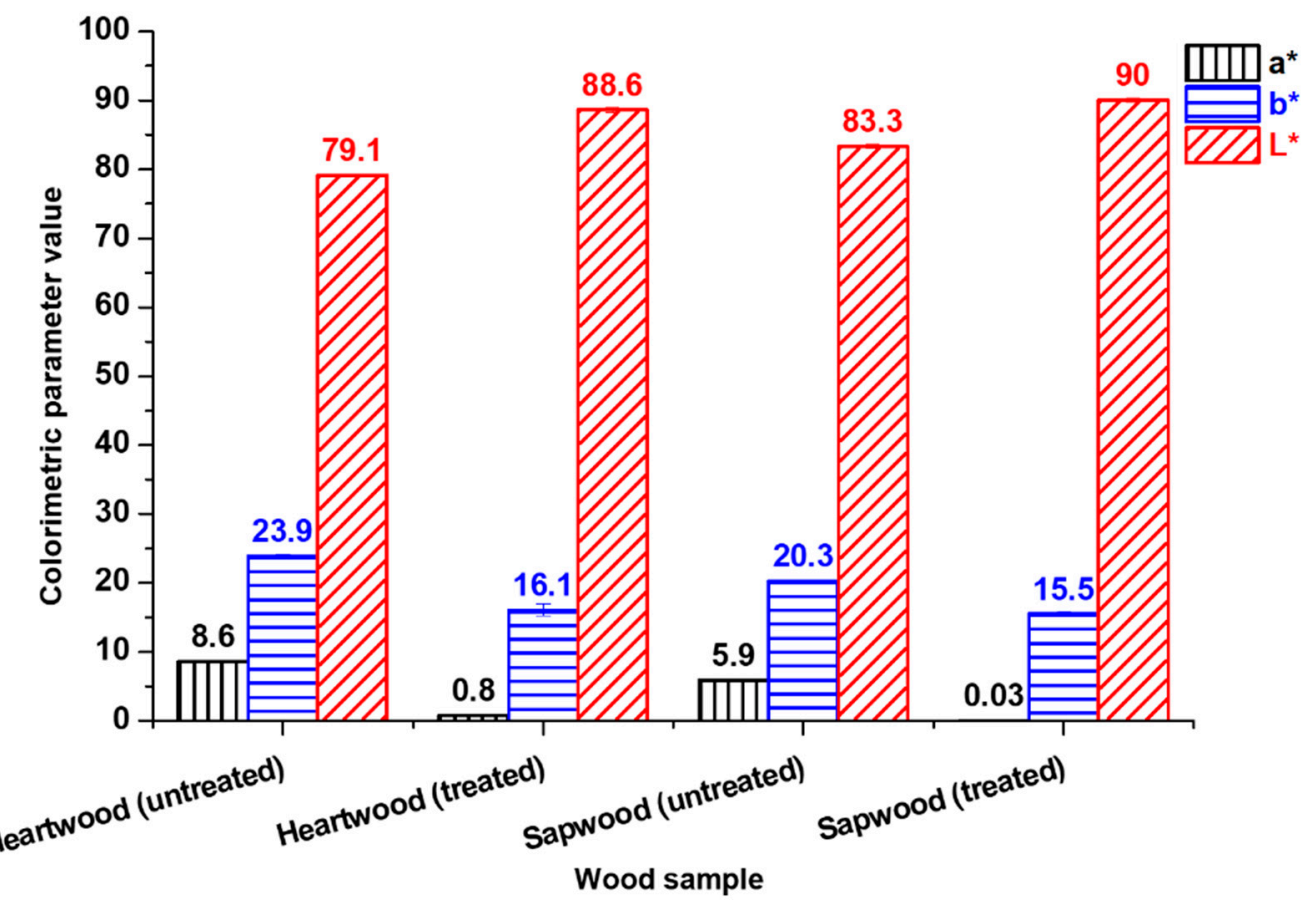

Figure 2. Influence of $\mathrm{H}_{2} \mathrm{O}_{2}$ treatment on maritime pine heartwood and sapwood colorimetric parameters.

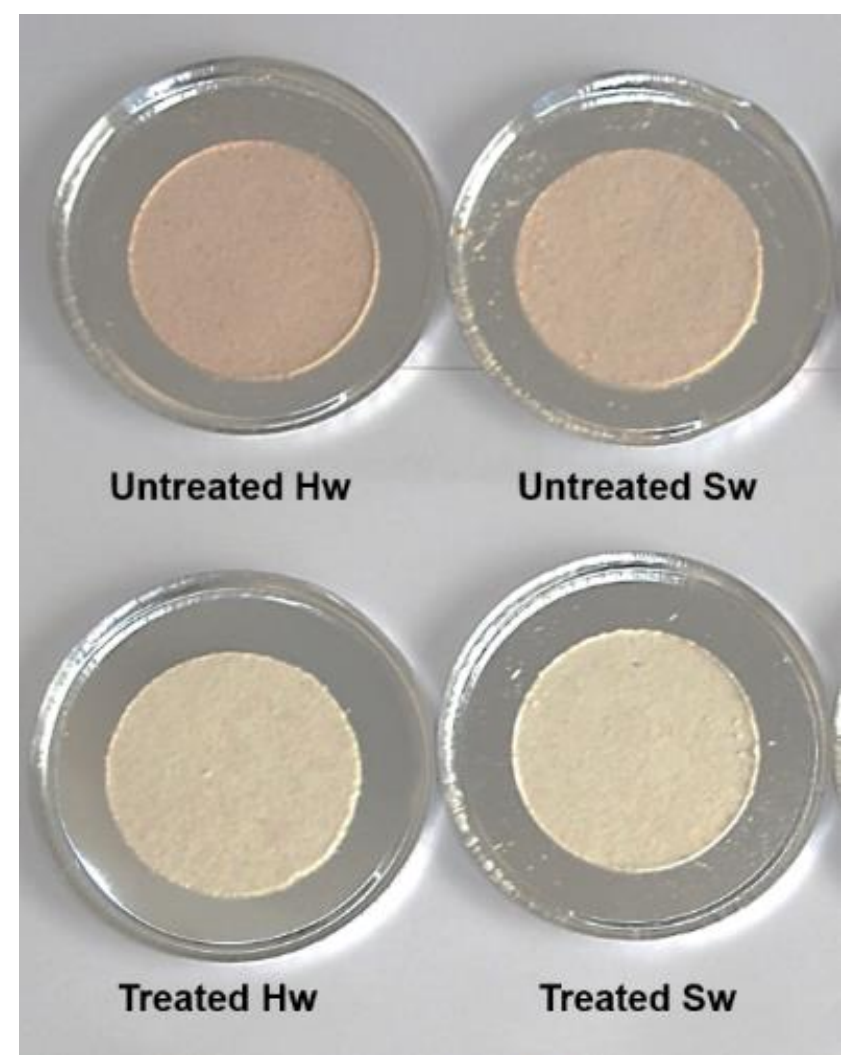

Figure 3. Maritime pine heartwood and sapwood discs before and after $\mathrm{H}_{2} \mathrm{O}_{2}$ treatment.

Color homogenization was attributed to two parameters:

- Extractives solubilization and modification: extractives have a high impact on wood color, especially heartwood's one and the redness ( $a^{*}$ parameter) is correlated with these secondary metabolites. 
- The alkaline environment during the treatment promotes the formation of carboxylates and phenolates, which are more soluble than native extractives, which leads to the decrease of $a^{*}$ values [35,36].

- Chemical modifications of unextractable wood chromophores (lignin and high molecular weight compounds formed from extractives): As mentioned previously, coniferaldehyde units and quinones have a major influence on wood color even if they are present in a low amount.

- Perhydroxyl anions can reacts with these structures [27,37]: Coniferaldehyde units are subjected to addition in $\alpha$ position that lead to an oxirane formation after rearrangement. After a final $\mathrm{HOO}^{-}$adding, methanoate anion as well as vanillin-type derivative are formed as shown in Figure 4a. The addition of $\mathrm{HOO}^{-}$leads to ringopening reactions for orthoquinone derivatives and to ring-degradation for paraquinone units (Figure 4c). Finally, colorless compounds called hydroquinones can be formed (Figure $4 b$ ) [38]. As determined in Forsskahl et al.'s study [39], methoxy- $p$ benzoquinone $\left(\lambda_{\max }=355 \mathrm{~nm}\right)$ is transformed into methoxy- $p$-benzohydroquinone $\left(\left(\lambda_{\max }=290 \mathrm{~nm}\right)\right.$.

a

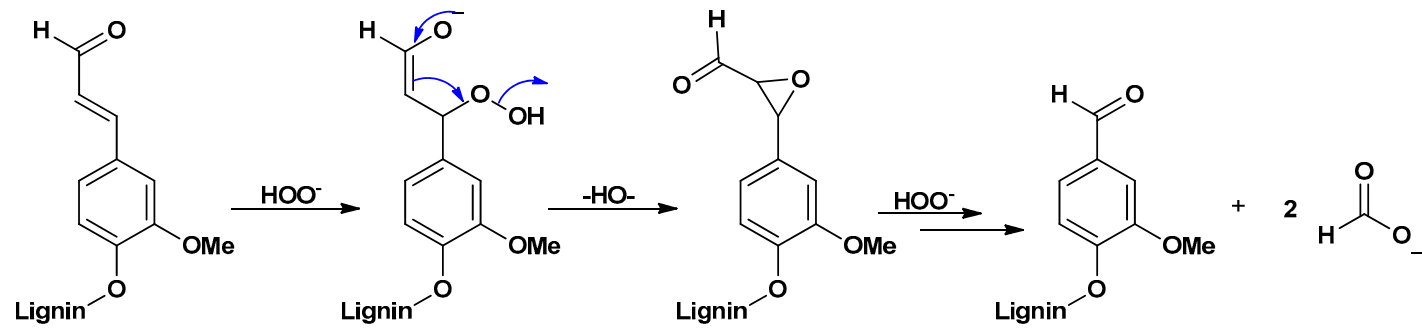

b
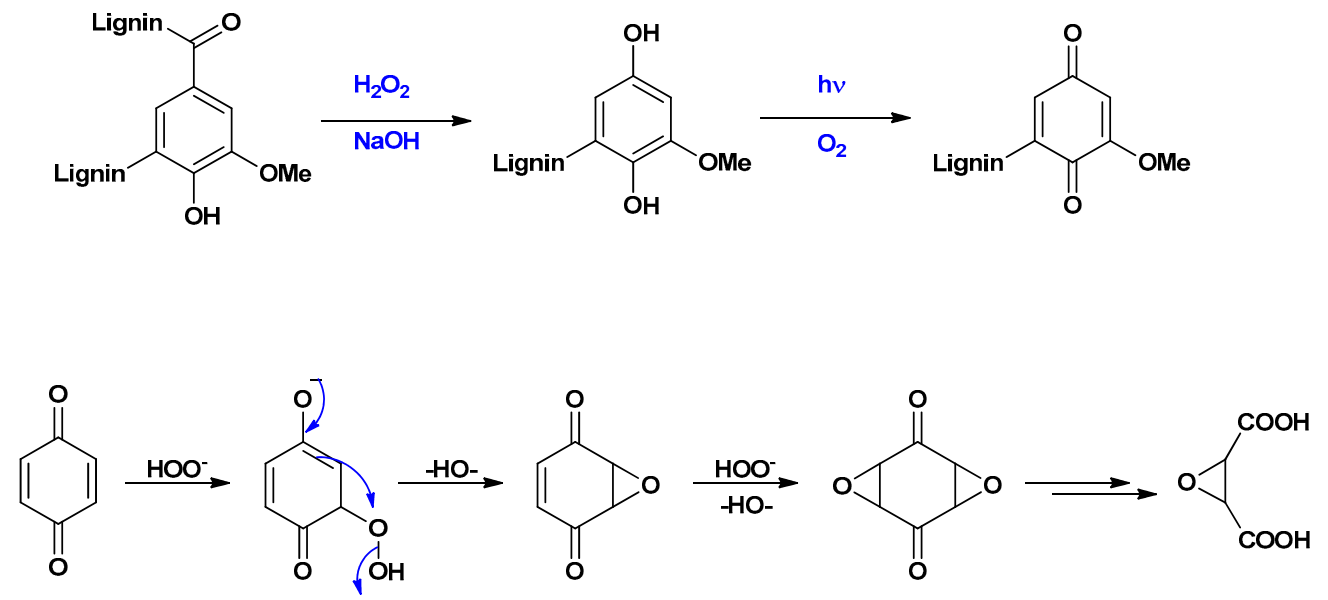

c
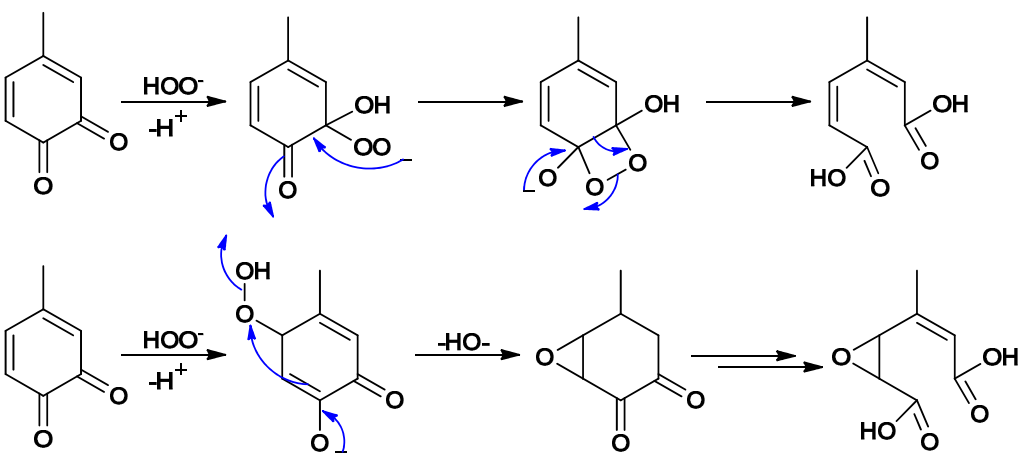

Figure 4. Reactions of perhydroxyl anions on coniferaldehyde units (a), vanillin-type units (b), and quinone-type units (c) $[27,37,38,40]$. 


\subsection{Influence of $\mathrm{NaOH}$ Concentration Variation and Treatment Duration $/ \mathrm{H}_{2} \mathrm{O}_{2}$ Consumption}

Hydrogen peroxide treatment is highly sensitive to the sodium hydroxide concentration. When a large amount of alkali is introduced in the solution, $\mathrm{H}_{2} \mathrm{O}_{2}$ may be totally consumed, which may generate secondary reactions that will induce alkaline darkening [41,42].

The impact of $\mathrm{NaOH}$ concentration was studied by monitoring the color difference between heartwood and sapwood.

In addition to the previous experiments with $1 \% \mathrm{NaOH}$, three new conditions (Table 1): low amount of $\mathrm{NaOH}(3), \mathrm{H}_{2} \mathrm{O}_{2}$ and $\mathrm{NaOH}$ in equimolar quantity (5), large excess of $\mathrm{NaOH}(6)$ were performed and the results were compared to untreated (1), control (2, water treated), and $1 \% \mathrm{NaOH}(4)$.

Table 1. $\mathrm{NaOH}$ concentration variation during $\mathrm{H}_{2} \mathrm{O}_{2}$ treatment.

\begin{tabular}{|c|c|c|c|c|c|c|}
\hline $\mathrm{NaOH} \% w$ & Untreated (1) & Control (water) (2) & $0.1 \%(3)$ & $1 \%(4)$ & $1.8 \%(5)$ & $10 \%(6)$ \\
\hline $\mathrm{H}_{2} \mathrm{O}_{2}$ concentration & np & $\mathrm{np}$ & $15 \mathrm{~g} \cdot \mathrm{L}^{-1}$ & $15 \mathrm{~g} \cdot \mathrm{L}^{-1}$ & $15 \mathrm{~g} \cdot \mathrm{L}^{-1}(0.047 \mathrm{~mol})$ & $15 \mathrm{~g} \cdot \mathrm{L}^{-1}$ \\
\hline $\mathrm{NaOH}$ concentration & $\mathrm{np}$ & np & $0.96 \mathrm{~g} \cdot \mathrm{L}^{-1}$ & $9.6 \mathrm{~g} \cdot \mathrm{L}^{-1}$ & $18 \mathrm{~g} \cdot \mathrm{L}^{-1}(0.047 \mathrm{~mol})$ & $96 \mathrm{~g} \cdot \mathrm{L}^{-1}$ \\
\hline
\end{tabular}

Treated and untreated heartwood and sapwood samples are observed in Figure 5, and Figure 6 shows the evolution of $\mathrm{L}^{*}, \mathrm{a}^{*}$, and $\mathrm{b}^{*}$ values versus the $\mathrm{NaOH}$ concentration in solution:

- $\quad \mathrm{L}^{*}$ parameter (Figure 6a): there is no significative difference between the experiments for heartwood. For sapwood on the other hand, $L^{*}$ values decrease with the increase of $\mathrm{NaOH}$ concentration.

- $\quad a^{*}$ parameter (Figure 6b): For heartwood as for sapwood, all values decrease compared to untreated powders but with no significative influence of $\mathrm{NaOH}$ concentration. The lowest difference is obtained for $1 \% \mathrm{w}$.

- $\quad b^{*}$ parameter: Values are strongly dependent on $\mathrm{NaOH}$ percentage shown in Figure $6 \mathrm{c}$ and keep increasing with the concentration, especially for heartwood samples. Consequently, wood powders treated with a solution containing $10 \% \mathrm{NaOH}$ look more yellow than the others as shown in Figure 6.

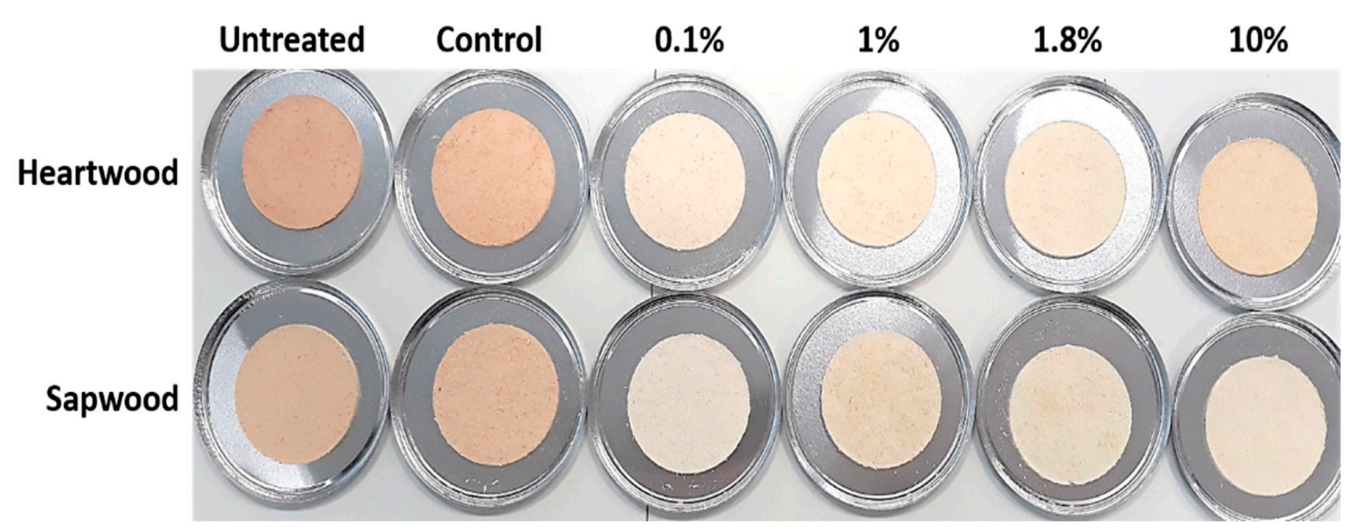

Figure 5. Impact of $\mathrm{NaOH}$ concentration variation on maritime pine wood color.

The best homogenization is obtained for $1 \% \mathrm{NaOH}$ as shown in Table 2. For lower $\mathrm{NaOH}$ concentration, $\Delta \mathrm{E}$ is high due to the brightness gap between heartwood and sapwood. For higher $\mathrm{NaOH}$ quantity, $\mathrm{b}^{*}$ parameter has the greatest impact on $\Delta \mathrm{E}$ as $\Delta \mathrm{b}^{*}$ values increase with the concentration. 

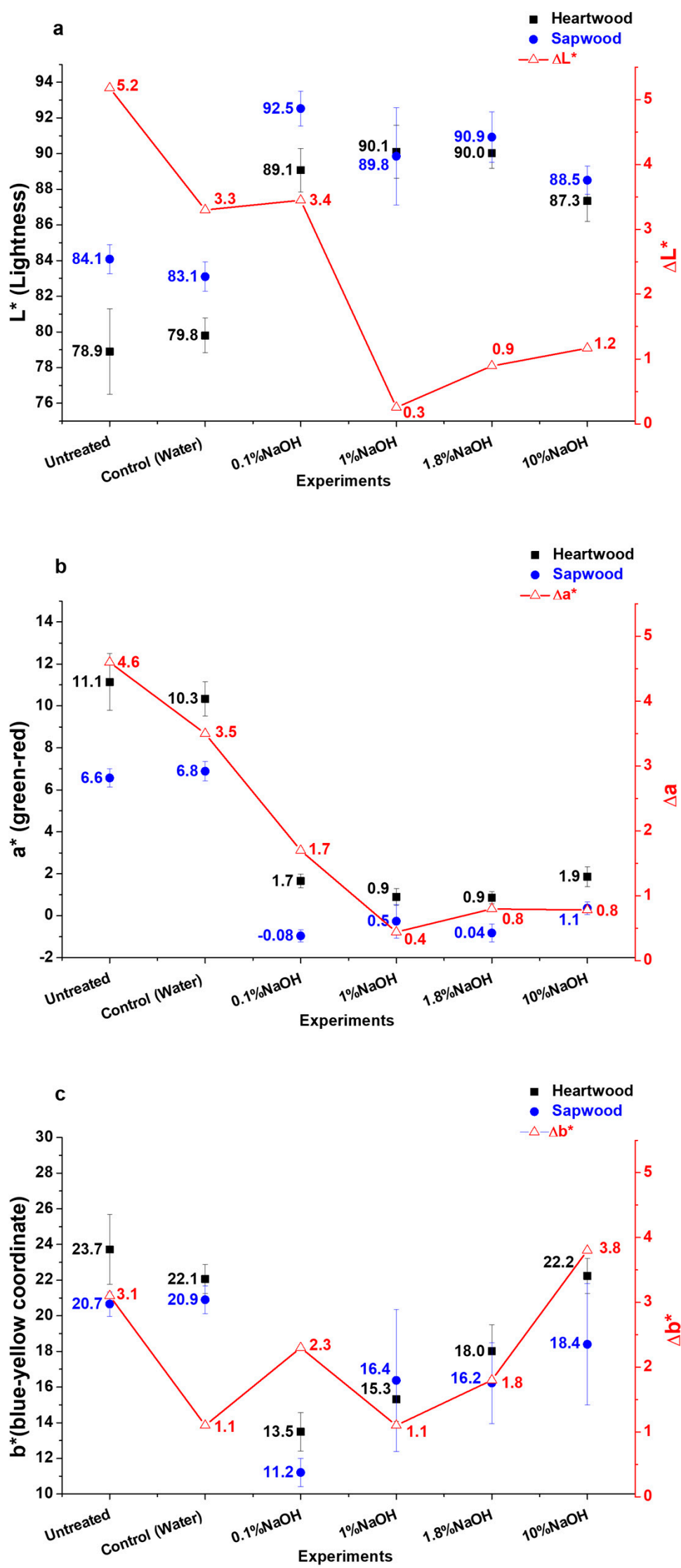

Figure 6. $\mathrm{L}^{*}(\mathbf{a}), \mathrm{a}^{*}(\mathbf{b})$, and $\mathrm{b}^{*}(\mathbf{c})$ values evolution depending on $\mathrm{NaOH}$ concentration during $\mathrm{H}_{2} \mathrm{O}_{2}$ treatment $\left(4 \% \mathrm{H}_{2} \mathrm{O}_{2}, 0.4 \% \mathrm{Na}_{2} \mathrm{SiO}_{3}, 60^{\circ} \mathrm{C} @ 1 \mathrm{~h}\right.$, mean of three replicates). 
Table 2. Influence of $\mathrm{NaOH}$ concentration on $\Delta \mathrm{E}_{\mathrm{Sw} / \mathrm{Hw}}$ values.

\begin{tabular}{ccccccc}
\hline $\mathbf{N a O H} \% w$ & Untreated (1) & Control (2) & $\mathbf{0 . 1 \%}(\mathbf{3})$ & $\mathbf{1 \%}(\mathbf{4})$ & $\mathbf{1 . 8 \%}(5)$ & $\mathbf{1 0 \% ( 6 )}$ \\
\hline$\Delta \mathrm{E}_{\mathrm{Sw} / \mathrm{Hw}}$ & 7.5 & 4.9 & 4.5 & 1.2 & 2.2 & 4.1 \\
\hline
\end{tabular}

In order to avoid alkaline darkening, $\mathrm{H}_{2} \mathrm{O}_{2}$ total consumption should be prevented. The consumption of hydrogen peroxide was monitored for the treatment with $1 \% \mathrm{NaOH}$ since this percentage leads to the best value of $\triangle \mathrm{E}$ and have been reported in Figure $7 \mathrm{a}$. $\mathrm{H}_{2} \mathrm{O}_{2}$ concentration decreases until $60 \mathrm{~min}$ of treatment and then remains stable. The oxidant is not totally consumed, which may prevent secondary reactions between hydroxyl anions and lignin. The correlation between $\mathrm{H}_{2} \mathrm{O}_{2}$ consumption and $\Delta \mathrm{E}$ evolution (Figure $\mathrm{7b}$ ) confirms that $\Delta \mathrm{E}$ does not change anymore when oxidant concentration reaches its minimum value.

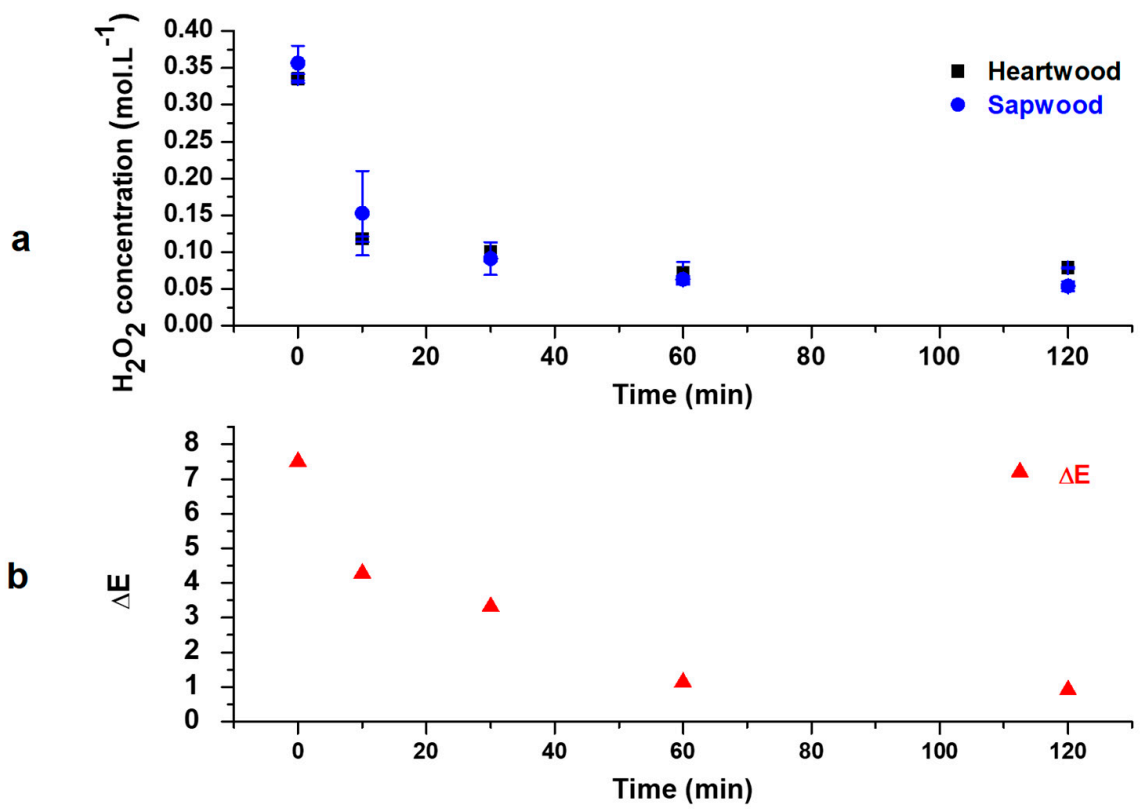

Figure 7. Evolution of $\mathrm{H}_{2} \mathrm{O}_{2}$ concentration (a) and $\Delta \mathrm{E}_{\mathrm{Sw}} / \mathrm{Hw}$ values (b) regarding time $\left(4 \% \mathrm{H}_{2} \mathrm{O}_{2}\right.$, $1 \% \mathrm{NaOH}, 0.4 \% \mathrm{Na}_{2} \mathrm{SiO}_{3}, 60^{\circ} \mathrm{C}$ ).

\subsection{Influence of $\mathrm{NaOH}$ Substitution by Magnesium Hydroxide}

As it was demonstrated previously, $\mathrm{NaOH}$ concentration in the solution is an important parameter to control. In order to get the best homogenization without yellowing reactions, $\mathrm{NaOH}$ was substituted with an alternative alkaline source: magnesium hydroxide $\left(\mathrm{Mg}(\mathrm{OH})_{2}\right)$. This compound is already used in replacement of $\mathrm{NaOH}$ in paper mill processes [43-47]. Sodium hydroxide was partially or totally replaced by $\mathrm{Mg}(\mathrm{OH})_{2}$ as presented in Table 3.

Table 3. $\mathrm{NaOH} / \mathrm{Mg}(\mathrm{OH})_{2}$ ratio variation during $\mathrm{H}_{2} \mathrm{O}_{2}$ treatment.

\begin{tabular}{cccccc}
\hline Experiments & $\mathbf{1}$ & $\mathbf{2}$ & $\mathbf{3}$ & $\mathbf{4}$ & $\mathbf{5}$ \\
\hline $\mathrm{H}_{2} \mathrm{O}_{2}$ percentage & $4 \%$ & $4 \%$ & $4 \%$ & $4 \%$ & $4 \%$ \\
$\mathrm{NaOH}$ percentage & $1 \%$ & $0.75 \%$ & $0.5 \%$ & $0.25 \%$ & $0 \%$ \\
$\mathrm{Mg}(\mathrm{OH})_{2}$ percentage & $0 \%$ & $0.25 \%$ & $0.5 \%$ & $0.75 \%$ & $1 \%$ \\
\hline
\end{tabular}

The very low solubility of $\mathrm{Mg}(\mathrm{OH})_{2}$ in water compared to $\mathrm{NaOH}\left(6.5 \mathrm{mg} \cdot \mathrm{L}^{-1}\right.$ vs. $1111 \mathrm{~g} \cdot \mathrm{L}^{-1}$, respectively), triggers the hydroxide anion concentration since they are generated more slowly, which may limit yellowing reactions. Figure 8 shows the influence of the $\mathrm{NaOH} / \mathrm{Mg}(\mathrm{OH})_{2}$ ratio on colorimetric parameters values. 

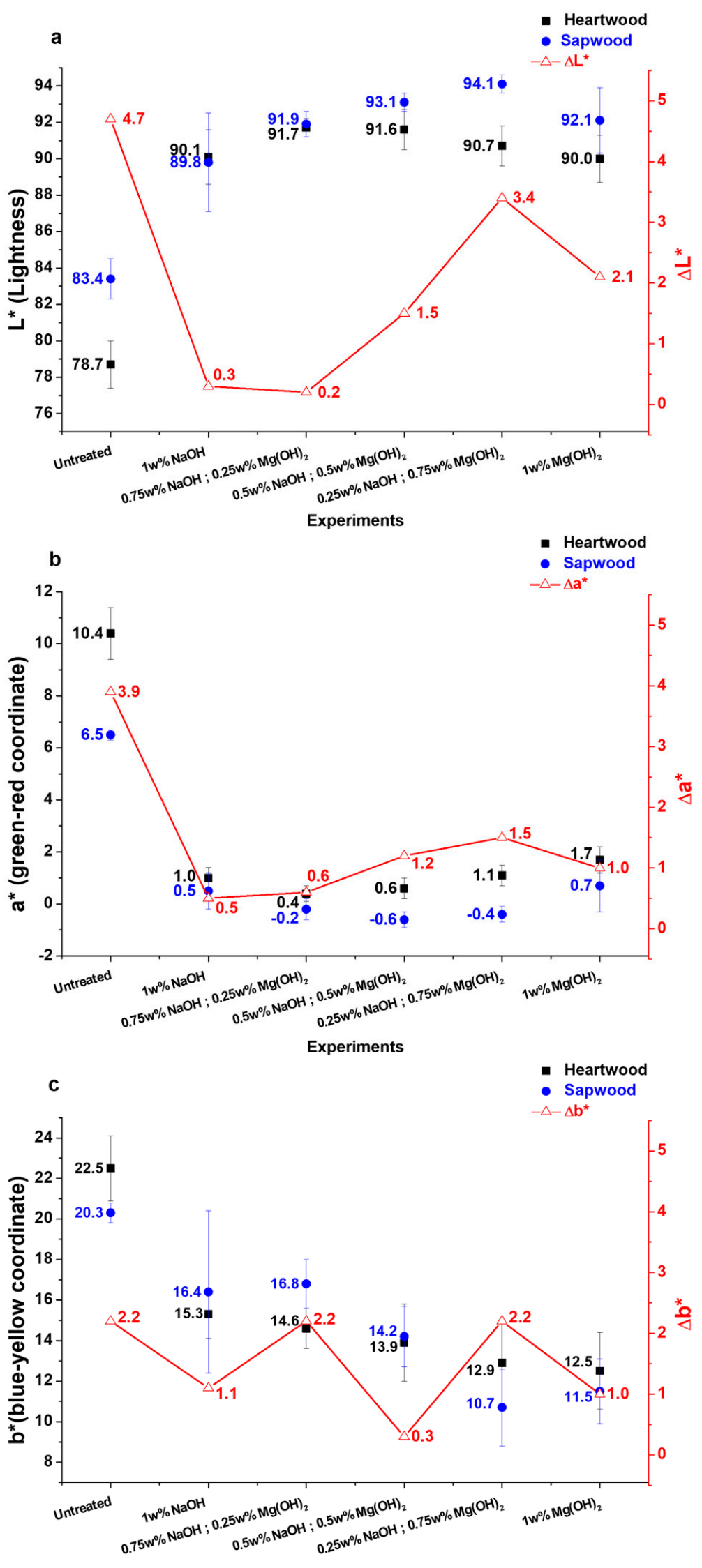

Experiments

Figure 8. $\mathrm{L}^{*}(\mathbf{a}), \mathrm{a}^{*}(\mathbf{b})$, and $\mathrm{b}^{*}(\mathbf{c})$ values evolution depending on $\mathrm{NaOH} / \mathrm{Mg}(\mathrm{OH})_{2}$ ratio during $\mathrm{H}_{2} \mathrm{O}_{2}$ treatment $\left(4 \% \mathrm{H}_{2} \mathrm{O}_{2}, 0.4 \% \mathrm{Na}_{2} \mathrm{SiO}_{3}, 60{ }^{\circ} \mathrm{C} @ 1 \mathrm{~h}\right.$, mean of three replicates). 
- $\quad L^{*}$ values increase when $\mathrm{NaOH}$ is partially replaced by $\mathrm{Mg}(\mathrm{OH})_{2}$. Nevertheless, there is a limit ratio beyond which a reversal trend is observed $\left(0.5 \% \mathrm{NaOH} / 0.5 \% \mathrm{Mg}(\mathrm{OH})_{2}\right.$ for heartwood, $0.25 \% \mathrm{NaOH} / 0.75 \% \mathrm{Mg}(\mathrm{OH})_{2}$ for sapwood). $\Delta \mathrm{L}^{*}$ values tend to increase with the substitution rate.

- For a* parameter, a decrease is observed until the ratio $0.5 \% \mathrm{NaOH} / 0.5 \% \mathrm{Mg}(\mathrm{OH})_{2}$, then values increase as for the gap between heartwood and sapwood. This trend may be easily explained by the difference of reactivity between the two alkalis. As mentioned before, the low solubility of $\mathrm{Mg}(\mathrm{OH})_{2}$ in water allows a gradual release of hydroxide anion that will have an effect on the solution $\mathrm{pH}$ (value around 8-9 vs. 11-12 for $\mathrm{NaOH}$ solutions) [48]. $\mathrm{Mg}\left(\mathrm{OH}_{2}\right.$ solubilizes in water to form first $\mathrm{Mg}(\mathrm{OH})^{+}$ $\left(\mathrm{pKs} \mathrm{Mg}(\mathrm{OH})_{2}=11.2\right)$ and then $\mathrm{Mg}^{2+}$ and $\mathrm{OH}^{-}\left(\mathrm{pKa}\left(\mathrm{Mg}^{2+} / \mathrm{Mg}(\mathrm{OH})^{+}\right)=11.4\right.$ while $\mathrm{pKa}(\mathrm{Na}+/ \mathrm{NaOH})=14.8)$ [49]. Due to the lower pKa of magnesium hydroxide, heartwood phenolic compounds should be less deprotonated and are still present. Consequently, $\mathrm{a}^{*}$ values are higher when sodium hydroxide is fully substituted by magnesium hydroxide. As those extractives are not available in sapwood, a* values are less affected.

- Finally $b^{*}$ values decrease with substitution rate and confirm that using $\mathrm{Mg}(\mathrm{OH})_{2}$ could limit wood yellowing by preventing secondary reactions with hydroxide anions.

$\Delta \mathrm{E}$ values presented in Table 4 shows that the substitution of $\mathrm{NaOH}$ by $\mathrm{Mg}(\mathrm{OH})_{2}$ leads to a color homogenization between heartwood and sapwood but not as effective as for a treatment using only $\mathrm{NaOH}$.

Table 4. $\Delta$ E evolution depending on $\mathrm{NaOH} / \mathrm{Mg}(\mathrm{OH})_{2}$ ratio during $\mathrm{H}_{2} \mathrm{O}_{2}$ treatment.

\begin{tabular}{ccccccc}
\hline Experiments & Untreated & $\mathbf{1}$ & $\mathbf{2}$ & $\mathbf{3}$ & $\mathbf{4}$ & $\mathbf{5}$ \\
\hline $\mathrm{H}_{2} \mathrm{O}_{2}$ percentage & $/$ & $4 \%$ & $4 \%$ & $4 \%$ & $4 \%$ & $4 \%$ \\
$\mathrm{NaOH}$ percentage & $/$ & $1 \%$ & $0.75 \%$ & $0.5 \%$ & $0.25 \%$ & $0 \%$ \\
$\mathrm{Mg}(\mathrm{OH})_{2}$ percentage & $/$ & $0 \%$ & $0.25 \%$ & $0.5 \%$ & $0.75 \%$ & $1 \%$ \\
$\Delta \mathrm{E}_{\mathrm{Sw}} / \mathrm{Hw}$ & 6.5 & 1.2 & 2.3 & 1.9 & 4.3 & 2.5 \\
\hline
\end{tabular}

The $4 \% \mathrm{H}_{2} \mathrm{O}_{2} / 0.5 \% \mathrm{NaOH} / 0.5 \% \mathrm{Mg}(\mathrm{OH})_{2}$ system shows color homogenization results as good as the $4 \% \mathrm{H}_{2} \mathrm{O}_{2} / 1 \% \mathrm{NaOH}$. $\mathrm{L}^{*}$ values are higher while $b^{*}$ values are lower when concentration in $\mathrm{Mg}(\mathrm{OH})_{2}$ increases, consequently wood powders seems brighter than those treated with only $\mathrm{NaOH}$.

\subsection{UV Irradiation Ageing and Color Evolution}

It is known that wood color is modified overtime [50,51] due to interactions with UV radiations in presence of dioxygen, which induce chemical processes by generating quinone derivatives [52-55]. These modifications depend on the wood species and on the weathering of the materials: in the case of outdoor applications, rain and humidity additionally induce a leaching phenomenon and a material destruction that is not observed in indoor applications. Finally, biodeterioration can also alter wood color.

As a consequence, heartwood and sapwood discs were irradiated in an UV irradiation chamber and color changes were monitored periodically for 70 days and compared to untreated samples. Only the irradiation of samples treated by a system $4 \% \mathrm{H}_{2} \mathrm{O}_{2} / 1 \%$ $\mathrm{NaOH}$ was studied here.

Figure 9 shows the evolution of colorimetric parameters values during the experiment. A fast color change is observed during the first week and until the 28th day, then a slower evolution takes place. For both samples, $\mathrm{L}^{*}$ values decrease while $\mathrm{a}^{*}$ and $\mathrm{b}^{*}$ values increase and the evolution seems to be higher for the treated wood as shown in Tables 5 and 6 . 

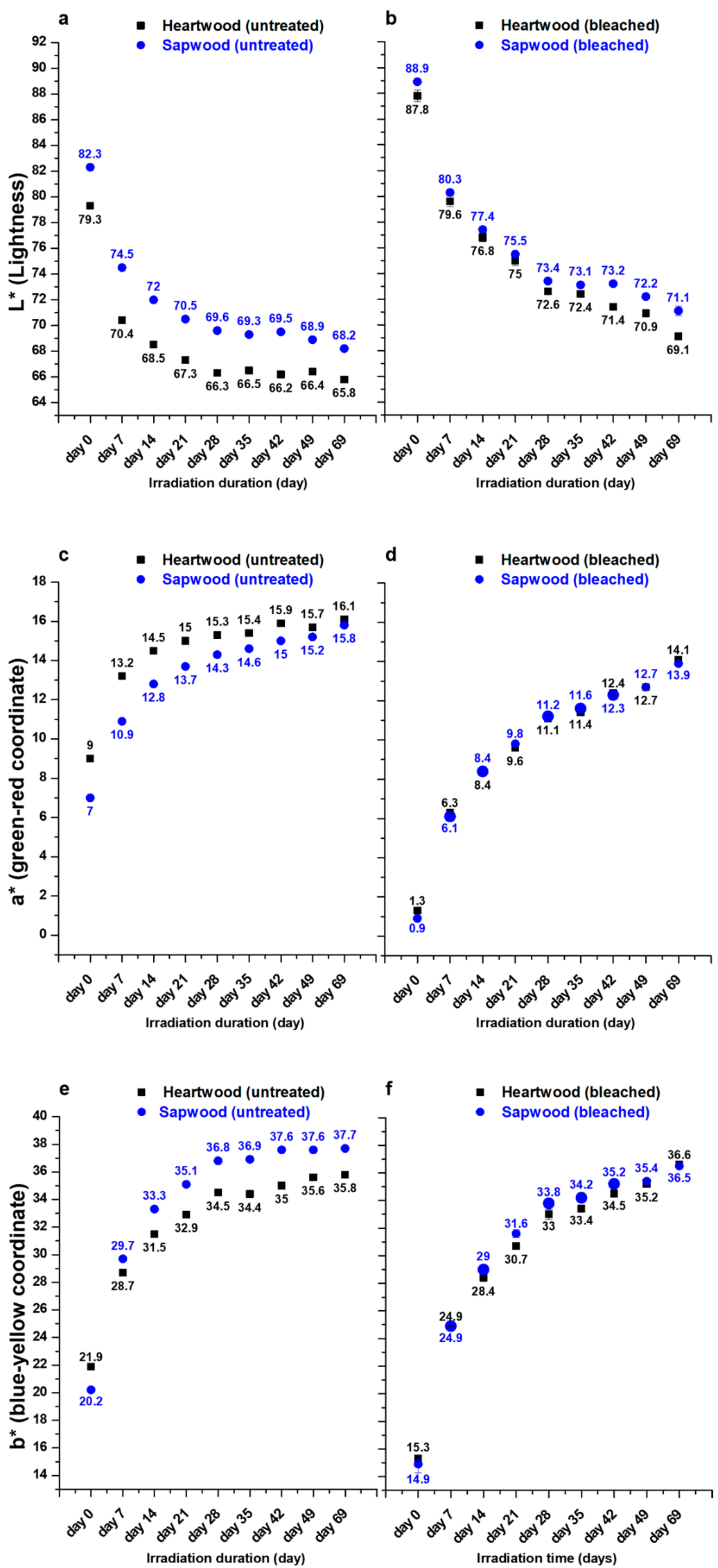

Figure 9. $L^{*}(\mathbf{a}, \mathbf{b}), \mathrm{a}^{*}(\mathbf{c}, \mathbf{d})$ and $b^{*}(\mathbf{e}, \mathbf{f})$ values evolution during UV irradiation treatment (untreated samples: a,c,e; $\mathrm{H}_{2} \mathrm{O}_{2}$ treated samples: $\left.\mathbf{b}, \mathbf{d}, \mathbf{f}\right)$. 
Table 5. Evolution of $\Delta \mathrm{L}^{*}, \Delta \mathrm{a}^{*}$, and $\Delta \mathrm{b}^{*}$ values of untreated and bleached heartwood between the first $(\mathrm{d} 0)$ and the last (d69) irradiation day.

\begin{tabular}{cccccc}
\hline \multicolumn{7}{c}{ Heartwood } \\
\hline & Untreated & & \multicolumn{2}{c}{ Bleached } \\
\hline$\Delta \mathrm{L}^{*}{ }_{\mathrm{d} 69 / \mathrm{d} 0}$ & $\Delta \mathrm{a}^{*} \mathrm{~d} 69 / \mathrm{d} 0$ & $\Delta \mathrm{b}^{*} \mathrm{~d} 69 / \mathrm{d} 0$ & $\Delta \mathrm{L}^{*}{ }_{\mathrm{d} 69 / \mathrm{d} 0}$ & $\Delta \mathrm{a}^{*} \mathrm{~d} 69 / \mathrm{d} 0$ & $\Delta \mathrm{b}^{*} \mathrm{~d} 69 / \mathrm{d} 0$ \\
\hline 13.5 & 7.1 & 13.9 & 18.7 & 12.8 & 21.3 \\
\hline
\end{tabular}

Table 6. Evolution of $\Delta \mathrm{L}^{*}, \Delta \mathrm{a}^{*}$, and $\Delta \mathrm{b}^{*}$ values of untreated and bleached sapwood between the first (d0) and the last (d69) irradiation day.

\begin{tabular}{cccccc}
\hline \multicolumn{7}{c}{ Sapwood } \\
\hline & Untreated & & \multicolumn{3}{c}{ Bleached } \\
\hline$\Delta \mathrm{L}^{*} \mathrm{~d} 69 / \mathrm{d} 0$ & $\Delta \mathrm{a}^{*} \mathrm{~d} 69 / \mathrm{d} 0$ & $\Delta \mathrm{b}^{*}{ }_{\mathrm{d} 69 / \mathrm{d} 0}$ & $\Delta \mathrm{L}^{*} \mathrm{~d} 69 / \mathrm{d} 0$ & $\Delta \mathrm{a}^{*} \mathrm{~d} 69 / \mathrm{d} 0$ & $\Delta \mathrm{b}^{*} \mathrm{~d} 69 / \mathrm{d} 0$ \\
\hline 14.1 & 8.8 & 17.5 & 17.8 & 13.8 & 21.6 \\
\hline
\end{tabular}

Chemical changes caused by UV irradiation ageing were observed by ATR analyses (Figure 10). The appearance of a band at $1710-1730 \mathrm{~cm}^{-1}$ is observed and attributed to the $\mathrm{C}=\mathrm{O}$ bond of quinone-type fragments formed as described in the mechanism presented in Figure 11.

- UV radiations in presence of dioxygen induce a hydrogen abstraction on lignin hydroxyl groups. The addition of oxygen radical species (perhydroxyl, hydroxyl) or dioxygen followed by rearrangements generate quinones [40,56].

- Quinones are produced from hydroquinones formed from lignin during $\mathrm{H}_{2} \mathrm{O}_{2}$ treatment [40].

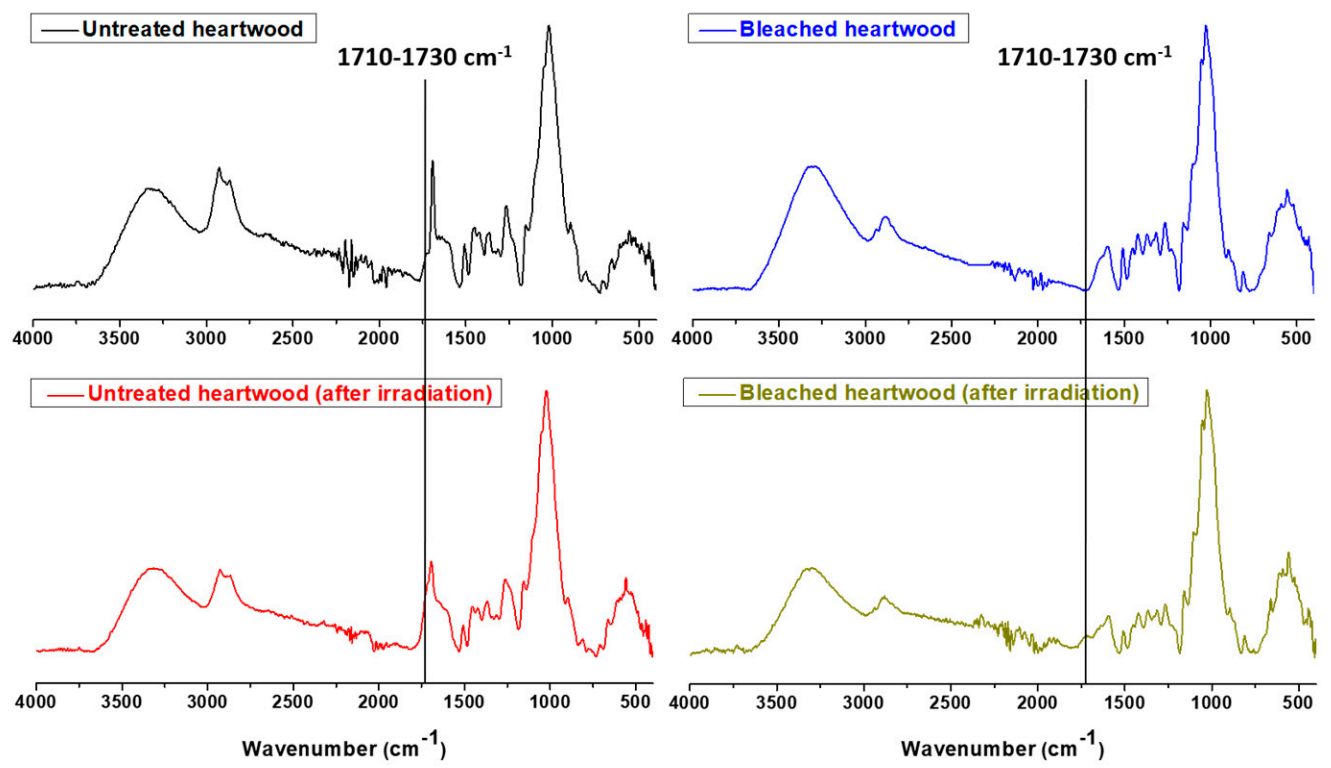

Figure 10. ATR traces of maritime pine heartwood (untreated and bleached) before and after UV irradiation ageing.

$\Delta \mathrm{E}$ values evolution was followed periodically during $\mathrm{UV}$ irradiation ageing; the results are presented in Figure 12. For untreated samples, an increase of the values is observed during the first week followed by a decrease. On the contrary, for bleached samples, a reverse trend occurs: a decrease during the first two weeks and then an increase. However, mean $\Delta \mathrm{E}$ for bleached samples is lower than the untreated sample one showing that the color difference between treated heartwood and sapwood stay low after 
ageing. A comparison between untreated, bleached, and irradiated/bleached samples is shown in Figure 13: due to the color reversion induced by UV rays, irradiated samples appear more yellow and dark than the others; however, color between the two domains remains homogeneous.

a<smiles>CCOOC1(OC)C=C(C(C)C)C=C(C)C1=O</smiles>

b

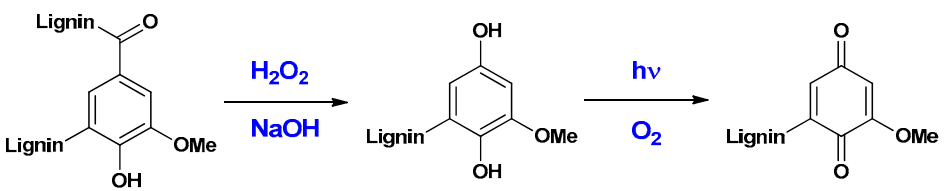

Figure 11. Quinone derivatives formation under the influence of UV irradiation (a) and evolution of hydroquinone formed from $\mathrm{H}_{2} \mathrm{O}_{2}$ treatment into quinone (b) $[40,56]$.

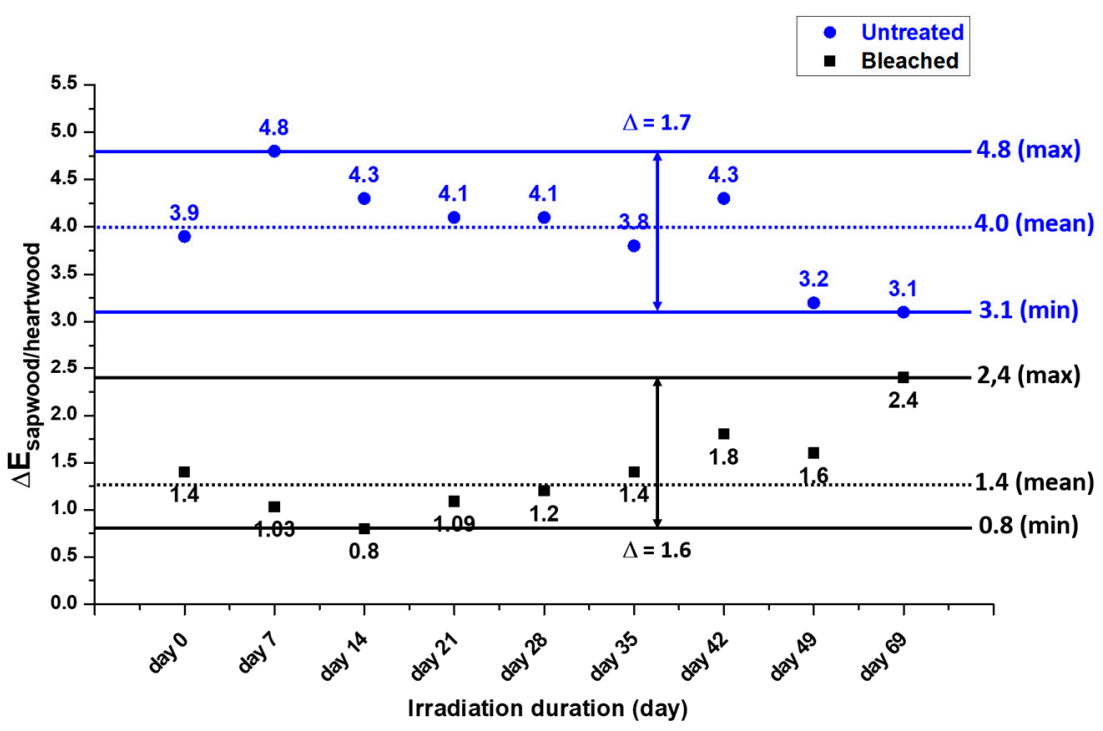

Figure 12. $\Delta$ E evolution of untreated and bleached samples during UV irradiation ageing. 


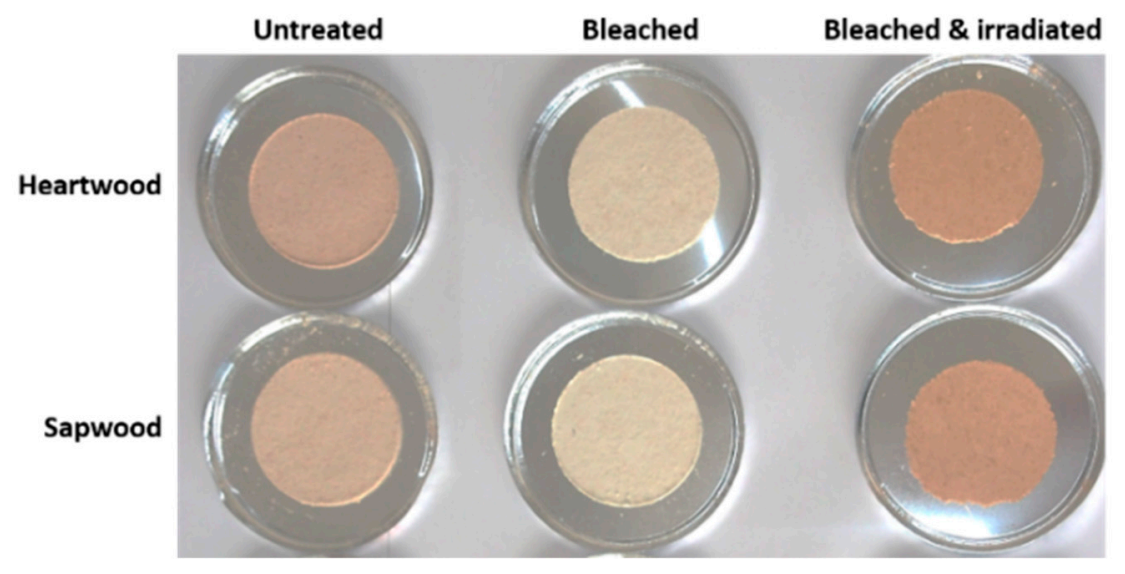

Figure 13. Comparison of untreated, bleached, and irradiated/bleached samples color.

\section{Conclusions}

Maritime pine heartwood and sapwood colors were homogenized with paper bleaching processes based on alkaline hydrogen peroxide chemistry. First, $\mathrm{H}_{2} \mathrm{O}_{2} / \mathrm{NaOH}$ solution was used, and wood surface are lighter and brighter than the untreated ones. This behavior is attributed to the modification of chromophores (coniferaldehyde, quinones) and to the extraction of extractives by formation of anionic species due to the alkaline environment.

When the percentage of alkali is high, the peroxide may be totally consumed, which may promote secondary reactions between hydroxyl anions and wood and, thus, leads to alkali darkening. The best homogenization result is obtained for the $4 \% \mathrm{H}_{2} \mathrm{O}_{2} / 1 \%$ $\mathrm{NaOH}$ system.

The substitution of $\mathrm{NaOH}$ by $\mathrm{Mg}(\mathrm{OH})_{2}$ leads to a decrease of $b^{*}$ parameter values and also to an increase of the $\mathrm{L}^{*}$ values. Consequently, samples treated with this system appear brighter than the one bleached with a $\mathrm{H}_{2} \mathrm{O}_{2} / \mathrm{NaOH}$ solution.

Due to his poor solubility in water, the release of hydroxyl is progressive, which may prevent alkali darkening reactions. Best color homogenization was obtained for the $4 \%$ $\mathrm{H}_{2} \mathrm{O}_{2} / 0.5 \% \mathrm{NaOH} / 0.5 \% \mathrm{Mg}(\mathrm{OH})_{2}$ system.

Finally, UV irradiation ageing experiments were carried out on both untreated and bleached samples. A color reversion was observed for all the samples irradiated and attributed to the formation of quinone derivatives. However, it was noted that the color between bleached heartwood and sapwood stayed homogeneous even after irradiation.

This preliminary study shows the effects of an alkaline hydrogen peroxide treatment on the color of maritime pine heartwood and sapwood powders. Facing these results, these experiments shall be applied on the treatment of veneer and solid wood considering the scale differences. Maritime pine wood is known to have a wide variability of extractives concentrations depending on the soil, the climate, or the position in the tree [57-60]. This parameter should be considered during the treatment and the composition of the hydrogen peroxide solution adapted to the material used.

Author Contributions: Conceptualization, S.G., L.C. and E.G.; Investigation, J.M.; Project administration, S.G., L.C.; writing — original draft preparation, J.M., S.G., writing—-review and editing, J.M., S.G.; Resources, J.M., L.C. All authors have read and agreed to the published version of the manuscript.

Funding: This study was financially supported by Gascogne Bois and ANRT.

Institutional Review Board Statement: No applicable.

Informed Consent Statement: No applicable.

Data Availability Statement: Data sharing not applicable.

Conflicts of Interest: The authors declare no conflict of interest. 


\section{References}

1. Rosa, R.; Soares, P.; Tomé, M. Evaluating the Economic Potential of Uneven-aged Maritime Pine Forests. Ecol. Econ. 2018, 143, 210-217. [CrossRef]

2. Gérard, J.; Guibal, D.; Paradis, S.; Vernay, M.; Beauchêne, J.; Brancheriau, L.; Châlon, I.; Daigremont, C.; Détienne, P.; Fouquet, D.; et al. Pin Maritime. Tropix 7 (Version 7.5.1) [Computer Software]. 2011. Available online: https://search.datacite.org/works/10.1 $8167 / 74726$ F706978 (accessed on 5 May 2021).

3. Rydholm, S.A. Pulping Processes; Interscience Publishers: Geneva, Switzerland, 1965.

4. Loras, V. Bleaching of mechanical and chemimechanical pulp. Sven. Papp. Nord. Cellul. 1981, 84, 36.

5. Pew, J.C.; Connors, W.J. Color of coniferous lignin. TAPPI J. 1971, 54, 245-247.

6. Adler, E. Carbonyl groups in lignin. I. Acta Chem. Scand. 1959, 13, 75-96. [CrossRef]

7. Adler, E. Recent studies on the structural elements of lignin. Pap. Puu. 1961, 43, 634-643.

8. Hon, D.N.-S.; Glasser, W. On possible chromophoric structures in wood and pulps: A survey of the present state of knowledge. Polym. Plast. Technol. Eng. 1979, 12, 159-179. [CrossRef]

9. Imsgard, F.; Falkehag, S.I.; Kringstad, K.P. On Possible Chromophoric Structures in Spruce Wood; Technical Association of the Pulp and Paper Industry: Peachtree Corners, GA, USA, 1971.

10. Kampe, A.; Magel, E. New Insights into Heartwood and Heartwood Formation. In Cellular Aspects of Wood, Formation; Fromm, J., Ed.; Springer: Berlin/Heidelberg, Germany, 2013; pp. 71-95.

11. Barton, G.M. Significance of western hemlock phenolic extractives in pulping and lumber. For. Prod. J. 1968, 18, 76-80.

12. Hrutfiord, B.F.; Luthi, R.; Hanover, K.F. Color Formation in Western Hemlock. J. Wood Chem. Technol. 1985, 5, 451-460. [CrossRef]

13. Burtin, P.; Jay-Allemand, C.; Charpentier, J.-P.; Janin, G. Natural wood colouring process in Juglans sp. (J. nigra, J. regia and hybrid J. nigra $23 \times$ J. regia) depends on native phenolic compounds accumulated in the transition zone between sapwood and heartwood. Trees 1998, 12, 258-264. [CrossRef]

14. Mayer, I.; Koch, G.; Puls, J. Topochemical investigations of wood extractives and their influence on colour changes in American black cherry (Prunus serotina Borkh). Holzforschung 2006, 60, 589-594. [CrossRef]

15. Dellus, V.; Scalbert, A.; Janin, G. Polyphenols and Colour of Douglas Fir Heartwood. Wood Res. Technol. 1997, 51, 291. [CrossRef]

16. Dellus, V.; Mila, I.; Scalbert, A.; Chimle, L.D.; Inra, B.; Thiverval-Grlgnon, N.A.P. Douglas-Fir polyphenols and heartwood formation. Phytochemistry 1997, 45, 1573-1578. [CrossRef]

17. Johansson, C.; Beatson, R.; Saddler, J. Fate and influence of western red cedar extractives in mechanical pulping. Wood Sci. Technol. 2000, 34, 389-401. [CrossRef]

18. Johansson, C.I.; Saddler, J.N.; Beatson, R.P. Characterization of the Polyphenolics Related to the Colour of Western Red Cedar (Thuja plicata Donn) heartwood. Holzforschung 2005, 54, 246-254. [CrossRef]

19. Gierlinger, N.; Jacques, D.; Grabner, M.; Wimmer, R.; Schwanninger, M.; Rozenberg, P.; Pâques, L. Colour of larch heartwood and relationships to extractives and brown-rot decay resistance. Trees Struct. Funct. 2004, 18, 102-108. [CrossRef]

20. Pâques, L.E.; del García-Casas, M.C.; Charpentier, J.-P. Distribution of heartwood extractives in hybrid larches and in their related European and Japanese larch parents: Relationship with wood colour parameters. Eur. J. For. Res. 2013, 132, 61-69. [CrossRef]

21. Bajpai, P. Environmentally Benign Approaches for Pulp Bleaching; Elsevier: Amsterdam, The Netherlands, 2012.

22. Gonzalez, P.; Zaror, C. Effect of process modifications on AOX emissions from kraft pulp bleaching, using Chilean pine and eucalyptus. J. Clean. Prod. 2000, 8, 233-241. [CrossRef]

23. Torrades, F.; Riva, M.C.; Torres, S.; Hortal, J.A.G.; Domènech, X.; Peral, J.; Pèrez, M. Detection and elimination of the constant error component and the interactive matrix interference in the determination of adsorbable organic halogen (AOX) in bleached kraft paper pulp mill effluents. Anal. Chim. Acta 1996, 333, 139-146. [CrossRef]

24. Yetis, U.; Selcuk, A.; Gokcay, C.F. Reducing chlorinated organics, AOX, in the bleachery effluents of a Turkish pulp and paper plant. Water Sci. Technol. 1996, 34, 97-104. [CrossRef]

25. Deshmukh, N.S.; Lapsiya, K.L.; Savant, D.V.; Chiplonkar, S.A.; Yeole, T.Y.; Dhakephalkar, P.K.; Ranade, D.R. Upflow anaerobic filter for the degradation of adsorbable organic halides (AOX) from bleach composite wastewater of pulp and paper industry. Chemosphere 2009, 75, 1179-1185. [CrossRef] [PubMed]

26. Martin, D.M. The bleaching of eastern spruce groundwood with alkaline peroxide. I. Reaction kinetics. TAPPI J. 1957, 40, 65-75.

27. Gellerstedt, G.; Agnemo, R. The reactions of lignin with alkaline hydrogen peroxide. Part III. The oxidation of conjugated carbonyl structures. Acta Chem. Scand. B 1980, 4, 34.

28. Colodette, J.L. Factors Affecting Hydrogen Peroxide Stability in the Brightening of Mechanical and Chemimechanical Pulps. Ph.D. Thesis, State University of New York College of Environmental Science and Forestry, New York, NY, USA, 1987.

29. Qiu, Z.; Ni, Y.; Yang, S. Using DTPA to decrease manganese-induced peroxide decomposition. J. Wood Chem. Technol. 2003, 23, 1-11. [CrossRef]

30. Mononen, K.; Jääskeläinen, A.-S.; Alvila, L.; Pakkanen, T.T.; Vuorinen, T. Chemical changes in silver birch (Betula pendula Roth) wood caused by hydrogen peroxide bleaching and monitored by color measurement (CIELab) and UV-Vis, FTIR and UVRR spectroscopy. Holzforschung 2005, 59, 381-388. [CrossRef]

31. Evans, P.D.; Palmer, G.; Chowdhury, M. Bleaching treatments for blue-stained lodgepole pine affected by the mountain pine beetle Dendroctonus ponderosae. Holz Roh-Werkst. 2007, 65, 485-486. [CrossRef] 
32. Technical Association of the Pulp and Paper Industry: TAPPI T257 cm-02. Sampling and Preparing Wood for Analysis. TAPPI Tests Methods, Atlanta. 2002. Available online: https://www.tappi.org/content/sarg/t257.pdf (accessed on 5 May 2021).

33. Baga, A.N.; Johnson, G.R.A.; Nazhat, N.B.; Saadalla-Nazhat, R.A. A simple spectrophotometric determination of hydrogen peroxide at low concentrations in aqueous solution. Anal. Chim. Acta 1988, 204, 349-353. [CrossRef]

34. Ekman, R.; Holmbom, B. The wood extractives in alkaline peroxide bleaching of groundwood from Norway spruce. Nord. Pulp Pap. Res. J. 1989, 4, 188-191. [CrossRef]

35. Holmbom, B.; Ekman, R.; Sjöholm, R.; Eckerman, C.; Thornton, J. Chemical changes in peroxide bleaching of mechanical pulps. Das Pap. (Darmstadt) 1991, 45, V16-V22.

36. Miao, Q.; Zhong, G.; Chen, L.; Huang, L. Influence of Alkaline Treatment and Alkaline Peroxide Bleaching of Aspen Chemithermomechanical Pulp on Dissolved and Colloidal Substances. Ind. Eng. Chem. Res. 2014, 53, 2544-2548. [CrossRef]

37. Castellan, A.; Grelier, S. Color and Color Reversion of Cellulosic and Lignocellulosic Fibers. In Lignocellulosic Fibers and Wood Handbook; John Wiley \& Sons, Ltd.: Hoboken, NJ, USA, 2016; pp. 531-551.

38. Gellerstedt, G.; Zhang, L. Formation of Leucochromophores during High-Yield Pulping and $\mathrm{H}_{2} \mathrm{O}_{2}$ Bleaching. Photochem. Lignocellul. Mater. 1993, 531, 129-146.

39. Forsskåhl, I.; Gustafsson, J.; Nybergh, A.; Vallén, S.; Enzell, C.R. The Photochemical Discolouration of Methoxy-p-benzoquinone in Solution. Acta Chem. Scand. 1981, 35, 389-394. [CrossRef]

40. Paulsson, M.; Parkås, J. Review: Light-Induced Yellowing of Lignocellulosic Pulps - Mechanisms and Preventive Methods. Bioresources 2012, 7, 5995-6040. [CrossRef]

41. Giust, W.; McLellan, F.; Whiting, P. Alkali darkening and its similarities to thermal reversion. J. Pulp Pap. Sci. 1991, 17, J73-J79.

42. He, Z.; Ni, Y.; Zhang, E. Alkaline Darkening and Its Relationship to Peroxide Bleaching of Mechanical Pulp. J. Wood Chem. Technol. 2005, 24, 1-12. [CrossRef]

43. Dietz, T.; Schmidt, K.; Suss, H.U. Aspects of Optimization of Mechanical Pulp Bleaching-A Comparison of Alternative Alkali Sources for Hydrogen Peroxide Bleaching. Int. Pap. 2008, 12, 39.

44. Hietanen, T.M.; Österberg, M.; Backfolk, K.A. Effects on Pulp Properties of Magnesium Hydroxide in Peroxide Bleaching. Bioresources 2013, 8, 2337-2350. [CrossRef]

45. Tamper, J.; Hietanen, T.; Manner, H. Alternative alkalis in peroxide bleaching of mechanical pulp. In Proceedings of the International Mechanical Pulping Conference, Minneapolis, MN, USA, 6-9 May 2007.

46. Ni, Y.; He, Z. Review Using magnesium hydroxide as the alkali source for peroxide bleaching of mechanical pulps-process chemistry and industrial implementation. Nord. Pulp Pap. Res. J. 2010, 25, 170-177. [CrossRef]

47. Suess, H.U.; Del Grosso, M.; Schmidt, K.; Hopf, B. Options for Bleaching Mechanical Pulp with Lower COD Load. In Proceedings of the 55th Appita Annual Conference, Hobart, Australia, 30 April-2 May 2001.

48. Zeinaly, F.; Shakhes, J.; Firozabadi, M.D.; Shakeri, A. Hydrogen peroxide bleaching of CMP pulp using magnesium hydroxide. Bioresources 2009, 4, 1409-1416.

49. Lide, D.R. CRC Handbook of Chemistry and Physics: A Ready-Reference Book of Chemical and Physical Data; Chemical Rubber Company, Ed.; CRC Press: Boca Raton, FL, USA, 2009.

50. Browne, F.L. The penetration of light into wood. For. Prod J. 1957, 7, 308-314.

51. Kataoka, Y.; Kiguchi, M. Depth profiling of photo-induced degradation in wood by FT-IR microspectroscopy. J. Wood Sci. 2001, 47, 325-327. [CrossRef]

52. Tolvaj, L.; Faix, O. Artificial Ageing of Wood Monitored by DRIFT Spectroscopy and CIE L*a*b* Color Measurements. 1. Effect of UV Light. Holzforschung 1995, 49, 397-404. [CrossRef]

53. Castellan, A.; Nourmamode, A.; Colombo, N.; Jaeger, C.; Noutary, C.; Zhu, J.H. Discoloration of phenolic carbonyl-free lignin model molecules, milled wood lignin (MWL) and peroxide MWL in the solid state; Approach to the mechanism of protection of high-yield pulps against photoyellowing by reducing agents using 3, 4-dimethoxy- $\alpha$-(2'-methoxyphenoxy) acetophenone as a lignin model. Australian Pulp and Paper Technical Association procedings. Wood Pulp. Chem. 1991, 10, 151-158.

54. Parkås, J.; Paulsson, M.; Li, S.; Lundquist, K.; Westermark, U. Photoyellowing behavior of non-phenolic lignin models representative of end groups and $\beta$-ether structures. Nord. Pulp Pap. Res. J. 2004, 19, 146-154. [CrossRef]

55. Ruffin, B.; Castellan, A. Photoyellowing of peroxide-bleached lignin-rich pulps: A photochemical study on stilbene-hydroquinone chromophores issued from $\beta-5$ units of lignin during refining and (or) bleaching. Can. J. Chem. 2000, 78, 73-83. [CrossRef]

56. Lin, S.Y.; Kringstad, K.P. Some reactions of photoinduced discoloration of lignin. Nor. Skogind. 1971, 25, 252.

57. Ghanmi, M.; El Abid, A.; Chaouch, A.; Aafi, A.; Aberchane, M.; El Alami, A.; Farah, A. Étude du rendement et de la composition de l'essence de térébenthine du Maroc: Cas du Pin maritime (Pinus pinaster) et du Pin d'Alep (Pinus halepensis). Acta Bot. Gallica 2005, 152, 3-10. [CrossRef]

58. Ghanmi, M.; Satrani, B.; Aafi, A.; Ismail, M.R.; Farah, A.; Chaouch, A. Évaluation de la qualité de la colophane du pin maritime (Pinus pinaster) et du pin d'Alep (Pinus halepensis) du Maroc. Acta Bot. Gallica 2009, 156, 427-435. [CrossRef]

59. Génova, M.; Caminero, L.; Dochao, J. Resin tapping in Pinus pinaster: Effects on growth and response function to climate. Eur. J. For. Res. 2013, 133, 323-333. [CrossRef]

60. Jactel, H.; Kleinhentz, M.; Marpeau-Bezard, A.; Marion-Poll, F.; Menassieu, P.; Burban, C. Terpene variations in maritime pine constitutive oleoresin related to host tree selection byDioryctria sylvestrella RATZ. (Lepidoptera: Pyralidae). J. Chem. Ecol. 1996, 22, 1037-1050. [CrossRef] [PubMed] 